\title{
Gangliosides in vivo reduce diabetes incidence in non-obese diabetic mice
}

\author{
S. Wilberz ${ }^{1}$, L. Herberg ${ }^{1}$ and A. E. Renold ${ }^{2 *}$ \\ ${ }^{1}$ Diabetes Research Institute, University of Düsseldorf, FRG and ${ }^{2}$ Institut de Biochimie clinique, University of Geneva, Switzerland
}

Summary. Non-obese diabetic mice were treated daily with a mixture of ganliosides from day 30 until day 250 of life or until the mice became diabetic. Ganglioside treatment reduced diabetes incidence from $80-90 \%$ to $47 \%$ and from $20-30 \%$ to zero in female and male mice respectively. Gangliosides did not affect the frequency of perivasculitis. It is concluded that gangliosides can reduce diabetes incidence in non-obese diabetic mice.

Key words: Gangliosides, cyclophosphamide, diabetes incidence, perivasculitis.
The non-obese diabetic (NOD) strain of mice develops diabetes spontaneously with a markedly higher incidence in female than in male mice [1]. Perivasculitis is the first sign of lymphocytic infiltration into pancreatic tissue and starts around day 15 of life [2]. Infiltration into the islets becomes noticeable by 4 weeks of age and results in an almost complete replacement of $B$ cells in the final stage [3].

Much data have been accumulated in support of immunological reactions contributing to the development of diabetes. Thus, NOD mice treated weekly with the $\mathrm{L} \mathrm{T} 4^{+}$-reactive rat monoclonal antibody GK 1.5 did not develop hyperglycaemia and mononuclear cell infiltration disappeared after 90 days of GK 1.5 administration. On withdrawal of therapy islet cell infiltration recurred, whereas blood glucose levels remained normal for more than 225 days [4].

Furthermore, grafting of cultured BALB $/ \mathrm{c}$ islets into diabetic NOD mice resulted in normalised blood glucose levels if the hosts were given antibody GK 1.5 [5]. In adoptive transfer experiments with spleen cells prepared from diabetic mice it was shown that $\mathrm{L}_{3} \mathrm{~T}^{+}$ T-lymphocytes are required to induce both insulitis and diabetes in neonatal and healthy young NOD mice [6].

The L3T4 molecule of the mouse corresponds to the CD4 molecule on human and rat T helper cells. In humans, rats, and mice the expression of CD4 molecules can be selectively suppressed in vitro by treat-

\footnotetext{
* Deceased
}

ment with gangliosides [7]. Based on these observations we tested if gangliosides could affect diabetes incidence in the NOD mouse.

\section{Material and methods}

\section{Mice}

NOD mice were used from our colony, the spontaneous diabetes incidence being $20-30 \%$ and $80-90 \%$ in males and females respectively.

\section{Treatment with gangliosides and cyclophosphamide}

Twelve male and 30 female mice were treated with gangliosides (Cronassial, Fidia, Res. Lab., Abano Therme, Italy, contained 21\% GM1, 40\% GD1a, 16\% GD1b, 19\% GT1b) from day 30 until day 250 of life or until they became diabetic. The daily dosage was $50 \mathrm{mg} / \mathrm{kg}$ body weight i.p. Twelve male and 31 female salinetreated mice served as controls. Ten 15 -week old male mice received a single dose of $200 \mathrm{mg}$ cyclophosphamide $/ \mathrm{kg}$ body weight i.p. (Serva, Heidelberg, FRG). Until day 20 when the mice were killed they were given a daily dose of $100 \mathrm{mg}$ Cronassial $/ \mathrm{kg}$ body weight i.p. (10 mice). Nine saline-treated male mice served as controls. Blood glucose (BG) was determined weekly. In case of obvious polyuria additional BG determinations were performed. Hyperglycaemia (diabetes) was diagnosed when BG levels were above $11.05 \mathrm{mmol} / \mathrm{l}$. In case of BG levels between $8.29-11.05 \mathrm{mmol} / \mathrm{l}$ for a period of 2-3 weeks the mice were called transiently hyperglycaemic.

At killing BG and plasma insulin levels as well as insulin in the pancreatic head and corpus were measured. BG was determined enzymatically, plasma insulin and acid alcohol-extracted pancreatic insulin were measured by Pharmacia-Insulin, Freiburg, FRG. Of the 


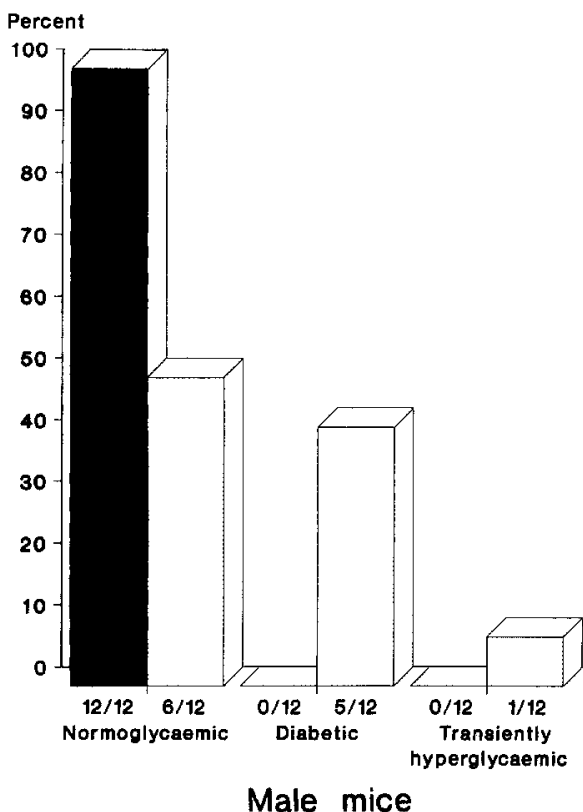

Bouin-fixed pancreatic tail 20 serial sections of $5 \mu \mathrm{m}$ each were prepared at $25 \mu \mathrm{m}$ intervals and stained with Aldehyde-Fuchsin. The ratio exocrine/endocrine tissue was determined morphometrically with a Kontron-Analyzer.

\section{Statistical analysis}

Statistical analyses were done by one-way-analysis of variance or by Chi-square test at a level of $p<0.05$.

\section{Results}

Of the ganglioside-treated group 14/30 (47\%) and $3 / 30(10 \%)$ female mice developed diabetes and transient hyperglycaemia, respectively, whereas all male mice remained normoglycaemic. Of the saline-treated group $18 / 31(58 \%)$ and $7 / 31(23 \%)$ female mice became diabetic and transiently hyperglycaemic respectively. In the saline-treated group of males diabetes oc- curred in $5 / 12(42 \%)$ and transient hyperglycaemia in $1 / 12$ (8\%) (Fig. 1).

Plasma insulin was slightly lower in diabetic than in normoglycaemic mice. Pancreas insulin, however, was significantly higher in the latter and 5-6-fold higher in transiently hyperglycaemic than in diabetic mice (Table 1). In normoglycaemic NOD mice of the ganglioside- or saline-treated group about $70 \%$ of the islets were infiltrated by lymphocytes. The frequency of perivasculitis was $22 / \mathrm{mm}^{2}$ and $28 / \mathrm{mm}^{2}$ in normoglycaemic mice of the ganglioside- and saline-treated group respectively. The ratio islet tissue/exocrine tissue was $0.5 \%$ and $0.2 \%$ in normoglycaemic ganglioside- and saline-treated mice respectively. This ratio was impressively reduced to $0.015 \%$ in hyperglycaemic mice of either group.

After pretreatment with cyclophosphamide diabetes developed in $7 / 10(70 \%)$ and $7 / 9(78 \%)$ of the ganglioside- and saline-treated mice respectively. Independent of the treatment pancreatic islets were com-

Table 1. Plasma and pancreas insulin in ganglioside- and saline-treated NOD mice

\begin{tabular}{|c|c|c|c|c|c|}
\hline \multirow[t]{2}{*}{ Treatment } & \multirow[t]{2}{*}{ Metabolic state } & \multicolumn{4}{|l|}{ Insulin } \\
\hline & & $\begin{array}{l}\text { Plasma } \\
(\mu \mathrm{U} / \mathrm{ml})\end{array}$ & $\begin{array}{l}\text { Not } \\
\text { tested }\end{array}$ & $\begin{array}{l}\text { Pancreas }^{\mathrm{a}} \\
(\mu \mathrm{U} / \mathrm{g})\end{array}$ & $\begin{array}{l}\text { Not } \\
\text { tested }\end{array}$ \\
\hline $\begin{array}{l}\text { Gangliosides } \\
\text { Saline }\end{array}$ & $\begin{array}{l}\text { Normoglycaemic } \\
\text { Normoglycaemic }\end{array}$ & $\begin{array}{l}12.5 \pm 1.4 \\
12.5 \pm 2.1\end{array}$ & $\begin{array}{l}23 \\
10\end{array}$ & $\begin{array}{l}472.2 \pm 83.6 \\
303.7 \pm 127.4\end{array}$ & $\begin{array}{l}23 \\
11\end{array}$ \\
\hline $\begin{array}{l}\text { Gangliosides } \\
\text { Saline }\end{array}$ & $\begin{array}{l}\text { Diabetic } \\
\text { Diabetic }\end{array}$ & $\begin{array}{l}8.7 \pm 1.4 \\
9.8 \pm 1.9\end{array}$ & $\begin{array}{l}14 \\
19\end{array}$ & $\begin{array}{l}20.8 \pm 3.7^{\mathrm{b}} \\
33.0 \pm \quad 8.1^{\mathrm{b}}\end{array}$ & $\begin{array}{l}14 \\
20\end{array}$ \\
\hline Gangliosides & $\begin{array}{l}\text { Transiently } \\
\text { hyperglycaemic }\end{array}$ & $\begin{array}{r}8.2 \\
12.9 \\
16.8\end{array}$ & 3 & $\begin{array}{r}62.9 \\
94.7 \\
242.5\end{array}$ & 3 \\
\hline Saline & $\begin{array}{l}\text { Transiently } \\
\text { hyperglycaemic }\end{array}$ & $6.9 \pm 0.3$ & 7 & $166.3 \pm 37.3$ & 6 \\
\hline
\end{tabular}

${ }^{\mathrm{a}}$ Head and corpus; ${ }^{\mathrm{b}}$ Diabetic vs the respective normoglycaemic mice, $p<0.05$ 
pletely replaced by lymphocytes in diabetic cyclophosphamide-pretreated mice. In contrast, the majority of islets were devoid of insulitis in the non-diabetic mice of either group.

\section{Discussion}

Gangliosides can impair various immunological processes such as the in vitro activation of lymphocytes by nonspecific mitogens [8]. Furthermore, inhibition of the infiltration of lymphocytes into pancreatic islets was observed after in vivo treatment of NOD mice with the anti-L3T4 antibody GK 1.5 [9].

We found that in ganglioside-treated female NOD mice the incidence of diabetes and transient hyperglycaemia declined from $80-90 \%$ to $47 \%$ whereas in males spontaneous incidence of $20-30 \%$ was prevented. However, in saline-treated male mice spontaneous incidence had increased to $50 \%$ whereas in saline-treated females the $81 \%$ incidence reflected well the spontaneous one. Since lymphocytic infiltration into pancreatic tissue starts as early as day 15 of life [2] one may speculate that ganglioside administration before day 30 of life might have prevented perivasculitis, insulitis and the development of transient hyperglycaemia and diabetes. In agreement with Nakajima et al. [10] treatment of NOD mice with cyclophosphamide increased the incidence of diabetes in male recipients. Pretreatment with cyclophosphamide, however, failed to affect the diabetes incidence of ganglioside-treated male mice. From the present data it is concluded that gangliosides reduce diabetes incidence in NOD mice. The frequency of perivasculitis in normoglycaemic NOD mice, however, is not modulated by gangliosides. Furthermore, gangliosides seem to affect the ratio islet tissue/exocrine tissue by favouring islet tissue.

It remains to be clarified whether the observed effects of gangliosides can be attributed to any potential action of theirs against T-lymphocytes and/or B cells.

Acknowledgements. We thank Prof. H.Gleichmann for critical reading of the manuscript. The study was supported by the Deutsche Forschungsgemeinschaft SFB 113 and the Landesamt für Forschung des Landes Nordrhein-Westfalen.

\section{References}

1. Makino S, Kunimoto K, Muraoka Y, Mizushima Y, Katagiri K, Tochino $Y(1980)$ Breeding of a non-obese, diabetic strain of mice. Exp Anim 29: 1-13

2. Miyazaki A, Hanafusa T, Yamada K, Miyagawa J, Fujino-Kurihara H, Nakajima H, Nonaka K, Tarui S (1985) Predominance of $\mathrm{T}$ lymphocytes in pancreatic islets and spleen of pre-diabetic non-obese diabetic (NOD) mice: a longitudinal study. Clin Exp Immunol 6: 622-630

3. Yui R, Fujita $T$ (1988) Islet pathology in NOD mice. In: Shafrir E, Renold AE (eds) Frontiers in diabetes research. Lessons from animal diabetes II. John Libbey, London Paris, pp $112-116$

4. Shizuru JA, Taylor-Edwards C, Banks BA, Gregory AK, Fathman CG (1988) Immunotherapy of the nonobese diabetic mouse: treatment with an antibody to $T$-helper cells. Science 240: 659-662

5. Wang Y, Hao L, Gill RG, Lafferty KJ (1987) Autoimmune diabetes in NOD mouse is L3T4 T-lymphocyte dependent. Diabetes 36: $535-538$

6. Bendelac A, Carnaud C, Boitard C, Bach JF (1987) Syngeneic transfer of autoimmune diabetes from diabetic NOD mice to healthy neonates. Requirement for both $\mathrm{L} \mathrm{T}_{4}{ }^{+}$and $\mathrm{Lyt}^{2}{ }^{2} \mathrm{~T}$ cells. J Exp Med 166: 823-832

7. Offner H., Thieme T, Vandenbark AA (1987) Gangliosides induce selective modulation of CD4 from helper T lymphocytes. J Immunol 139: 3295-3305

8. Whiler RL, Yates AJ (1980) Regulation of lymphocyte responses by human gangliosides. I. Characteristics of inhibitory effects and the induction of impaired activation. J Immunol 125: 2106-2111

9. Koike T, Itoh $Y$, Ishi T, Ito I, Takabayashi K, Maruyama N, To mioka H, Yoshida S (1987) Preventive effect of monoclonal antL3T4 antibody on development of diabetes in NOD mice. Diabetes 36: $539-541$

10. Nakajima H, Fujino-Kurihara $H$, Hanafusa T, Yamada $K$, Miyazaki A, Miyagawa J, Nonaka K, Tarui S, Tochino Y (1985) Nicotinamide prevents the development of cyclophosphamideinduced diabetes mellitus in male non-obese diabetic (NOD) mice. Biomed Res 6: 185-189

Received: 22 September 1988

Prof. Dr. Dr. L. Herberg

Diabetes Forschungsinstitut

an der Universität Düsseldorf

Auf'm Hennekamp 65

D-4000 Düsseldorf 1

FRG 